\title{
PENINGKATAN EFISIENSI PRODUKSI BACK COVER TV BERBAHAN BAKU ABS MELALUI PENGURANGAN CACAT PRODUK DENGAN METODE TAGUCHI
}

\author{
Kasum*,Syahbuddin** \\ PT LG Electronics Indonesia, Jakarta* \\ Magister Teknik Mesin Universitas Pancasila, Jakarta**
}

\begin{abstract}
ABSTRAK
Efesiensi produksi back cover TV berbahan baku ABS melalui pengurangan cacat produk dianalisis dalam penelitian ini. Metode yang digunakan adalah metode Taguchi untuk menentukan parameter setting optimum selama proses injeksi. Simulasi moldflow digunakan untuk memprediksi aliran cairan ABS dengan 16 gates serta modifikasi dengan flow leader juga dilakukan dalam penelitian ini. Hasil penelitian diperoleh nilai parameter optimum tekanan injeksi $119 \mathrm{MPa}$, tekanan holding $50 \mathrm{MPa}$, kecepatan injeksi $70 \mathrm{~mm} / \mathrm{s}$, dan temperatur melt $220{ }^{\circ}$ C. Aliran cairan ABS didalam cetakan dengan flow leader lebih merata dan weld line lebih kecil dibandingkan dengan kondisi awalnya. Cacat produksi di perusahaan jika diprosentasekan sebesar 0,9\% dan khusus untuk cacatflash nilainya 0,1\%.
\end{abstract}

Kata Kunci: Cacat Produk, Taguchi, Moldflow, ABS, Flow Leader

\section{PENDAHULUAN}

Back Cover merupakan salah satu komponen yang digunakan sebagai penutup belakang LED TV. Memiliki ukuran 1.244,6 $\mathrm{mm}$ (49 inci) dan dikategorikan kedalam LED TV berukuran besar.Proses manufaktur yang digunakan untuk memproduksinya yaitu injection molding. Selama produksi berlangsung sering mengalami masalah cacat kualitas seperti flash, weld line, flow mark dan lain sebagainya. Kondisi cacat flash seperti terlihat digambar berikut.

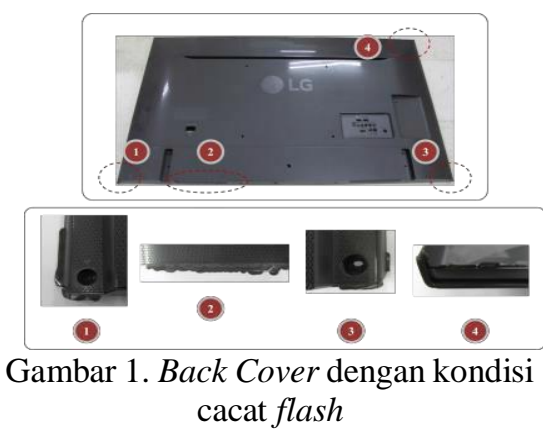

Akibat adanya flash waktu siklus bertambah dan material terbuang. Waktu pemotongan rata-rata $5 \mathrm{~s}$, artinya waktu siklus bertambah sebesar nilai tersebut, akibatnya effisiensi produksi menjadi kurang optimal. Produktifitas back cover saat ini. Perusahaan ingin mengurangi cacat tersebut dengan cara mencari nilai optimum parameter injeksinya.

Beberapa penelitian [1, 2] yang telah dilakukan untuk mengurangi cacat adalah dengan cara mengatur parameter injeksi untuk memperoleh nilai optimumnya sehingga cacat dapat diminimalisir sampai pada tingkat terendah. Peneliti [1] menggunakan parameter tekanan injeksi, tekanan holding, kecepatan injeksi dan temperatur melt untuk mengurangi cacat flash. Metode taguchi digunakan untuk mendapat nilai parameter optimumnya dan hasilnya cacat produk dapat diturunkan.

Penelitian sebelumnya tidak menyebutkan bagaimana keseimbangan aliran melt di dalam cetakan dan jumlah gate yang digunakan. Keseimbangan aliran melt pada penelitian ini akan di cek terlebih dahulu dengan menggunakan shoftware Moldflow, jika diketahui tidak seimbang maka dilakukan perbaikan mold dan disimulasikan kembali untuk verifikasinya. Metode Taguchi digunakan untuk mendapatkan parameter pengaturan yang optimum untuk menurunkan tingkat cacat Back Cover dan meningkatkan efisiensinya.

\section{METODOLOGI}

Peneliti melakukan langkahlangkah berikut untuk memperbaiki cacat di back cover. 


\subsection{Identifikasi parameter injeksi}

\author{
Proses injeksi melibatkan banyak \\ parameter seperti, tekanan injeksi, \\ kecepatan injeksi, temperatur, waktu \\ pendinginan, tekanan holding dan lain \\ sebagainya. Untuk menentukan \\ parameter yang dipilih peneliti \\ melakukan brainstorming dengan pihak \\ perusahaan dan diplot menggunakan \\ diagram tulang ikan. Hasilnya, parameter \\ yang paling berpengaruh terhadap cacat \\ flash di back cover adalah \\ 1. Tekanan injeksi \\ 2. Tekanan holding \\ 3. Kecepatan Injeksi \\ 4. Temperatur melt \\ Level untuk setiap faktornya dapat \\ dilihat ditabel berikut.
}

Tabel 1. Faktor-faktor dan level penelitian

\begin{tabular}{|l|c|c|c|}
\multicolumn{1}{|c|}{ Faktor } & \multicolumn{3}{c|}{ Level } \\
\cline { 1 - 1 } Tekanan Inieksi. A (MPa) & 105 & $\mathbf{2}$ & $\mathbf{3}$ \\
\hline Tekanan Holding, B (MPa) & 30 & 40 & 50 \\
\hline Kecepatan Injeksi, C & 60 & 70 & 80 \\
\hline Temperatur Melt, D $\left({ }^{\circ} \mathrm{C}\right)$ & 210 & 220 & 230 \\
\hline
\end{tabular}

\subsection{Simulasi aliran melt}

Aliran melt didalam cetakan disimulasikan menggunakan Autodesk Moldflow Insigh 2016. Material yang diunakan adalah ABS HF390. Apabila terjadi ketidakseimbangan aliran maka dillakukan perbaikandengan menambah flow leader. Sebelum diaplikasikan, hasil perbaikan disimulasikan terlebih dahulu menggunakan simulator yang sama.

\subsection{Optimasi parameter setting}

Metode Taguchi digunakan untuk mencari parameter setting yang optimum. Orthogonal Array yang dipilih adalah L9 dengan total eksperimen sebanyak 9 kali. Karakteristik kualitas yang dipilih yaitu lower is bettersebab penelitian ini berhubungan dengan cacat produk sehingga jika cacatnya lebih kecil maka akan lebih baik.

\section{STUDI LITERATUR}

Plastik adalah salah satu bentuk dari polimer, ABS adalah salah satunya.
Polimer ini memiliki karakteristik aliran laminar dan membentuk flow front pada bagian depannya dan umumnya yang digunakan bersifat reversible atau dapat didaur ulang. Polimer memiliki tiga fasa yaitu padat, elastis dan cair. Polimer dengan fasa padat memiliki karakteristik keras dan getas, fasa elastis polimer memiliki karakteristik kenyal dan fleksibel dan dibatasi oleh $\mathrm{Tg}$ (glass transision temperature). Fasa terakhir adalah cair, polimer cair ini biasa disebut dengan istilah melt atau molten. Fasa ini dibatasi oleh Tm (melt temperature), pada fasa inilah polimer cair diinjeksikan ke dalam cetakan.

\subsection{Injection Molding}

Injection molding merupakan salah satu proses yang digunakan dalam industri produk berbahan baku polimer. Proses ini yang paling umum digunakan untuk mengubah bentuk produk dari material polimer menjadi berbagai produk untuk industri seperti otomotif, elektronik, kesehatan, olahraga, rumah tangga dan sebagainya [8].

Proses injeksi melibatkan beberapa komponen utama yaitu mesin injeksi (injection molding machine), cetakan (mold) dan material (polimer). Disamping itu ada komponen pendukung lainnya seperti dehumidifier, mold temperature control (MTC), hopper dryer dan lain-lain. Satu komponen lagi yang sangat penting dalam proses injeksi adalah desain dari produk itu sendiri, dengan desain yang baik maka akan diperoleh hasil produk yang baik pula.

Komponen mesin injeksi terdiri dari unit clamping, unit molding, dan unit injeksi. Prosesnya pertama adalah melelehkan

/memanaskan polimer sampai melebihi temperatur lelehnya sehingga mudah untuk dialirkan kedalam cetakan. Proses ini dilakukan didalam mesin pelelehan atau barrel yang dilengkapi screw, berfungsi untuk mengalirkan melt kedalam cetakan. Proses yang kedua adalah menahan melt didalam cetakan sampai membeku dan sesuai dengan bentuk cetakan yang dibuat. Proses yang ketiga adalah proses mengeluarkan produk dari cetakan.

\subsection{Parameter Injeksi}

Parameter settingmerupakan parameterparameter yang harus dikontrol pada saat 
proses injeksi berlangsung karena akan menentukan kualitas produk yang dihasilkan. Selain itu parameter setting juga sangat berpengaruh pada efektifitas biaya produksi yang harus dikeluarkan untuk membuat sebuah produk. Ada empat parameter dasar untuk proses injection molding yaitu: temperatur, tekanan, waktu dan jarak.

Semua polimer memiliki rentang temperatur proses, pada rentang tersebut terdapat temperatur yang paling efisien dimana polimer mudah untuk diinjeksikan dengan tetap mempertahankan sifat fisiknya dinilai maksimum [8]. Proses injeksi memerlukan tekanan dan pengontrol/pengendalinya, baik untuk unit injeksi (injection unit) maupun unit penjepitnya (clamping unit). Beberapa takanan yang digunakan pada proses injeksi diantaranya adalah tekanan injeksi, tekanan holding (holding pressure) dan tekanan penjepit (clamping pressure). Tekanan injeksi merupakan tekanan awal untuk pengisian didalam cetakan, tekanan holding merupakan tekanan terakhir untuk menjaga bentuk produk, dan tekanan clamping berfungsi untuk menjaga cetakan tetap tertutup.

\subsection{Cacat Produk Injeksi}

Kompleksitas proses injection molding dan ketergantungan antar banyak variabel yang terlibat, berarti bahwa setiap cacat produk mungkin memiliki beberapa penyebab yang berbeda. Cacat-cacat produk yang sering terjadi yaitu flash,weld line, flow mark, burn mark dan lain-lain.

\subsection{Metode Taguchi}

Salah satu metode peningkatan kualitas pada produk plastik adalah dengan perancangan kualitas pada proses injection moulding. Sebab proses pencetakan polimer tidak akan bisa diubah atau diperbaiki setelah proses pencetakan selesai. Perencanaan kualitas pada produk polimer harus dilakukan pada awal proses dengan cara mengatur faktorfaktor yang berpengaruh pada proses pencetakan agar menghasilkan produk yang bermutu. Proses tersebut lebih dikenal dengan proses desain produk. Adapun salah satu metode perbaikan mutu pada tahap desain adalah robust design yang diperkenalkan oleh Genichi Taguchi. Metode ini cukup handal untuk mengurangi cacat produk dengan jumlah eksperimen yang lebih sedikit.
Karakteristik Taguchi dibagi menjadi tiga yaitu higher is better, lower is better dan nominal is the best. Jumlah eksperimen yang dibutuhkan ditentukan oleh jumlah faktor dan level yang dipilih. Berdasarkan hal tersebut maka dapat ditentukan OA (orthogonal array) yang digunakan untuk eksperimen.

\section{HASIL dan PEMBAHASAN}

\section{Simulasi}

Moldflow

Berdasarkan hasil simulasi diperoleh data gambar aliran melt didalam cetakan sebagai berikut:

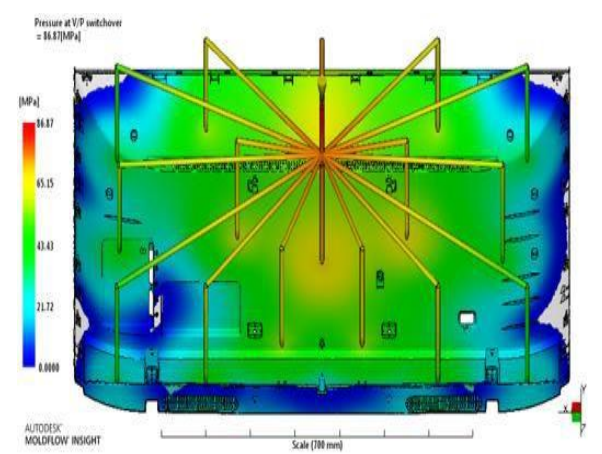

Gambar 1. Hasil simulasi moldflow kondisi awal, sebelum perbaikan

Diketahui bahwa aliran melt didalam cetakan tidak seimbang. Area bawah, sudut kanan dan kiri sudah terisi akan tetapi sudut kanan dan kiri atas belum terisi. Kondisi ini yang diduga sebagai penyebab terjadinya flash, oleh karena itu perlu dilakukan perbaikan dengan membuat flow leader seperti tampak pada gambar 2.Flow leader pada gambar ditunjukkan dengan area berwarnah merah dan berbentuk melengkung kearah sudut kanan dan kiri dengan ketebalan 0,3 mm.

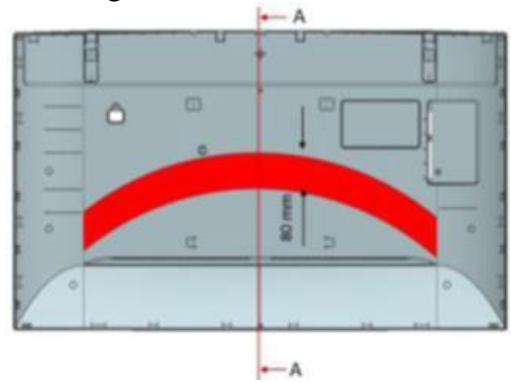

Gambar 2. Back Cover dengan flow leader

Evaluasi dilakukan untuk memastikan aliran melt lebih seimbang dengan perbaikan ini dan hasil simulasinya 
dapat dilihat pada gambar berikut.

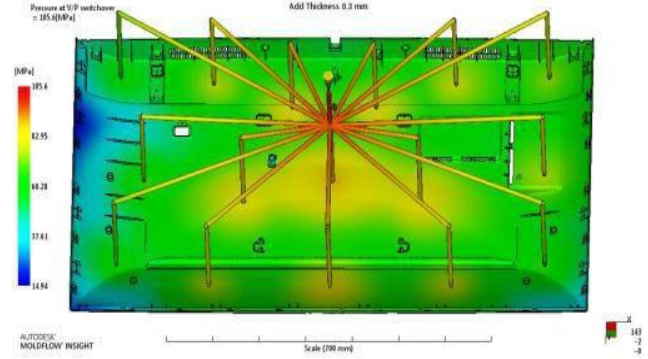

Gambar 3. Hasil simulasi setelah perbaikan dengan menambah flow leader.

Berdasarkan gambar 3 diketahui bahwa aliran melt didalam cetakan lebih seimbang dibandingkan dengan kondisi sebelumnya. Keseimbangan aliran ini ditunjukan dengan gradasi warna hijau yang merata.

Simulasi moldflow insight dapat digunakan juga untuk memprediksi posisi terjadinya weld line. Weld line terjadi karena adanya pertemuan dua aliran melt dan akibatnya akan menurunkan kekuatan secara mekanik ditempat terjadinya cacat tersebut. Dari hasil simulasi diperoleh gambaran sebagai berikut:

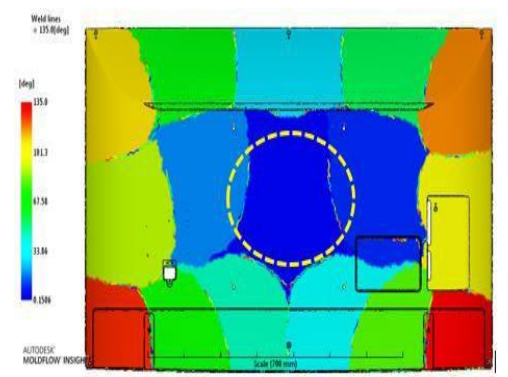

Gambar 4. Posisi weld line hasil simulasi moldflow

Berbeda ketika back cover ditambah flow leader, posisi weld line pada area tengah seperti yang dijelaskan diparagraf sebelumnya lebih sedikit, hal ini bisa dilihat pada gambar 5 sebagai hasil simulasi moldflow.

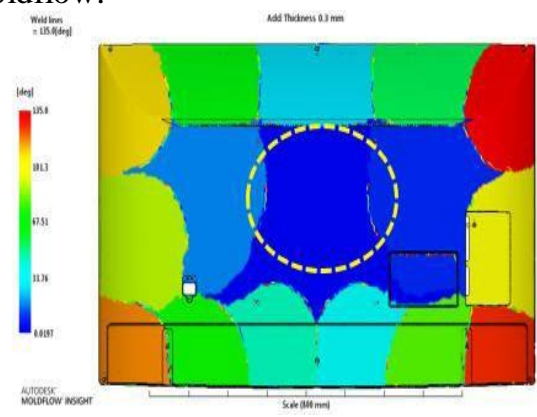

Gambar 5 Posisi weld line hasil simulasi moldflow dengan flow leader
Berdasarkan gambar 5 terlihat bahwa dengan area yang sama seperti pada gambar 4 garis yang bergelombang lebih sedikit atau lebih pendek, hal ini berarti bahwa dengan penambahan flow leader dapat menggeser dan mengurangi weld line. Aliran melt didaerah flow leader lebih cepat sehingga melt dapat tercampur saat temperatur masih cukup tinggi sehingga weld line yang terjadi lebih sedikit. Terbukti pula pada aktual produk tidak terlihat adanya weld line.

\section{Optimasi Parameter Injeksi}

Perhitungan untuk mengetahui efek dari rata-rata. Perhitungan dilakukan menggunakan excel dan diplot dalam bentuk grafik menggunakan Minitab 17 dan hasilnya seperti tampak pada tabel dan grafik berikut.

Tabel 2 Tabel efek untuk rata-rata

\begin{tabular}{|l|c|c|c|c|}
\hline & A & B & C & D \\
\hline Level 1 & 2,595 & 2,538 & 2,540 & 2,542 \\
\hline Level 2 & 2,461 & 2,544 & 2,537 & 2,532 \\
\hline Level 3 & 2,559 & 2,533 & 2,538 & 2,541 \\
\hline Effect & 0,134 & 0,012 & 0,003 & 0,010 \\
\hline Rank & 1 & 2 & 4 & 3 \\
\hline Optimum & $\mathrm{A} 2$ & $\mathrm{~B} 3$ & $\mathrm{C} 2$ & $\mathrm{D} 2$ \\
\hline
\end{tabular}

Dari data efek setiap faktor dapat dilihat urutan faktor mulai dari yang bernilai kecil sampai yang bernilai besar. Nilai efek yang besar menunjukkan bahwa faktor tersebut memiliki pengaruh yang besar dan nilai efek kecil menunjukkan pengaruh yang rendah. Rata-rata respon tiap-tiap faktor dipilih yang paling kecil sebagai rancangan usulan sebab seperti yang sudah disebutkan sebelumnya karakteristik mutu untuk cacat flash adalah smaller the better. Hasil yang sama diperoleh ketika perhitungan dilakukan dengan Minitab dan diplot dalam bentuk grafik.

Perhitungan efek SNR dilakukan untuk melihat seberapa besar pengaruhnya terhadap cacat produk.

Nilai SNR menunjukkan besarnya noise yang mempengaruhi sistem. Pada penelitian ini SNR dihitung berdasarkan kategori lebih kecil lebih baik (lower is better). Kategori ini dipilih karena cacat flash berhubungan dengan berat, umumnya produk dengan kondisi flash lebih berat dari 
produk tanpa cacat flash. Noise tidak dapat dikontrol hanya dapat diturunkan dengan cara mengoptimumkan parameter terkontrol dan pada penelitian ini parameter terkontrolnya adalah tekanan injeksi, tekanan holding, kecepatan injeksi dan temperatur melt. Hasil perhitungan efek SNR dapat dilihat pada gambar berikut.

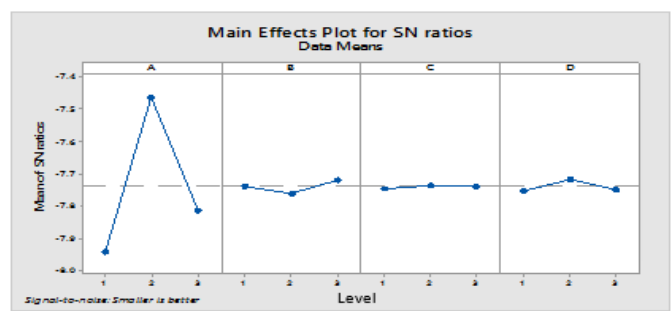

Gambar 6 grafik Main effect plot for SN ratios

Faktor A (tekanan injeksi) memiliki efek yang besar dibanding dengan faktor lainnya terhadap nilai SNR, artinya nilai noise dapat diturunkan dengan cara mencari nilai tekanan injeksi yang optimum. Berdasarkan tabel 2 dan 3 dapat dilihat bahwa urutan ranking dan nilai optimumnya sama untuk mean dan SNR. Ranking untuk mean berturut turut faktor $\mathrm{A}=1, \mathrm{~B}=2, \mathrm{C}=4$ dan $\mathrm{D}=3$. Nilai optimum untuk setiap faktornya sama juga yaitu A2, B3, C2 dan D2. Berdasarkan hal tersebut maka secara berturut- turut nilai parameter setting optimum adalah tekanan injeksi $=119$ $\mathrm{MPa}$, tekanan holding =

$50 \mathrm{MPa}$, kecepatan injeksi $=70 \mathrm{~mm} / \mathrm{s}$ dan temperatur melt $=220{ }^{\circ} \mathrm{C}$. Jadi parameter optimum injeksi jika ditabelkan sebagai berikut:

Tabel 3 Parameter setting usulan

\begin{tabular}{|l|c|}
\hline \multicolumn{1}{|c|}{ Faktor } & $\begin{array}{l}\text { Setting } \\
\text { Parameter }\end{array}$ \\
\hline Tekanan Injeksi, A $(\mathrm{MPa})$ & 119 \\
\hline Tekanan Holding, B $(\mathrm{MPa})$ & 50 \\
\hline Kecepatan Injeksi, C $(\mathrm{mm} / \mathrm{s})$ & 70 \\
\hline Temperatur Melt, $\mathrm{D}\left({ }^{\circ} \mathrm{C}\right)$ & 220 \\
\hline
\end{tabular}

Data setting tersebut selanjutnya dicoba dan diaplikasikan untuk memproduksi back cover TV LED dan diperoleh produk dengan kondisi

flash jauh lebih sedikit dibanding dengan kondisi sebelumnya. Flash sedikit terjadi dipojok kanan bawah dengan demikian proses pemotongan lebih cepat dari sebelumnya. Proses pemotongan sebelumnya empat titik dan kondisi saat ini proses pemotongan hanya satu titik yaitu dibagian sudut kanan bawah dengan waktu 1 detik, artinya lebih cepat 3 detik dari proses sebelumnya.

Waktu siklus mesin 80 detik jika ditambah dengan waktu pemotongan maka waktu siklus totalnya menjadi 81 detik. Jika dibandingkan dengan kondisi sebelumnya waktu siklus lebih cepat 5 detik. Jumlah back cover yang dihasilkan dalam satu jam menjadi 44 buah atau 2 buah lebih banyak dari sebelumnya. Dengan kata lain dengan menggunakan semetode Taguchi produksi back cover naik $4,76 \%$ per jam.

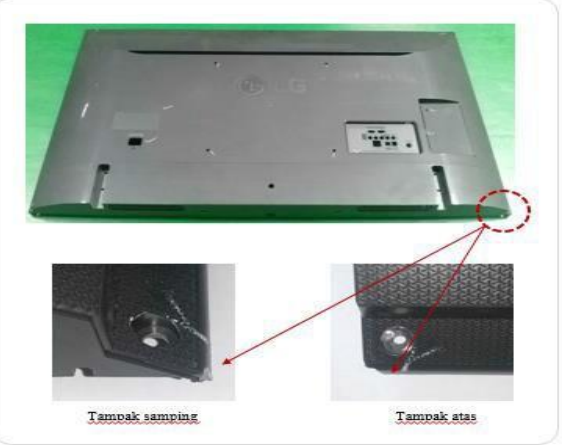

Gambar 7. Back Cover 1.244,6 mm (49 inci) dengan setting optimum

\section{KESIMPULAN}

1. Metode Taguchi mampu untuk menurunkan tingkat cacat flash dan weld line. Cacat flash tidak hilang sama sekali akan tetapi volumenya turun signifikan, dimana kondisi produk sebelumnya memiliki volume flash 4 posisi dan setelah dilakukan setting ulang menggunakan metode Taguchi menjadi hanya satu posisi dan flash nya pun sangat kecil. Cacat weld line masih ada tetapi lebih tersamar, sehingga ketika produksi masal tidak lagi ditemukan cacat tersebut. J umlah total produksi selama dua bulan diperoleh data total prosentase cacat produk sebesar $0,9 \%$ dan untuk cacat flash hanya $0,1 \%$.

2. Perhitungan menggunakan metode Taguchi dengan antuan software Minitab 17 dan Microsoft Excel diperoleh nilai parameter setting optimum berturut-turut: tekanan 
injeksi sebesar $119 \mathrm{MPa}$, tekanan holding sebesar $50 \mathrm{MPa}$, kecepatan injeksi sebesar $70 \mathrm{~mm} / \mathrm{s}$ dan temperature melt sebesar $220{ }^{\circ} \mathrm{C}$. Kondisi setting parameter ini terbukti stabil untuk menjaga kualitas back cover tetap stabil karena rate cacat produknya sangat kecil.

3. Penambahan flow leader pada produk back cover dapat mengurangi weld line. Kondisi ini dapat dibuktikan melalui simulasi moldflow dimana kondisi garis weld line lebih pendek dari sebelumnya, sebab flow leader dapat membantu menyeimbangkan aliran melt (flow balanced).

\section{Daftar Pustaka}

[1]. Kalpesh S. Kamble, Baliram Jadhav and Ramjan Kalmadi, Investigation and Analysis of The Active Factors to Address the Defect in Injection Molding Process, Proceeding of $7^{\text {th }}$ IRF International Conference, Pune, India, 2014.

[2]. M.V. Kadave and S. D. Kadam, Parameter Optimization of Injection Molding of Polypropilene by using Taguchi Methodology, IOSR Journal of Mechanical and Civil Engineering, 2012.

[3]. Didik W, Gan Shu San and Yohan Pramono, Optimasi Proses Injeksi dengan Metode Taghuci, Jurnal Teknik Mesin, Universitas Kristen Petra, Vol. 3, 2001, No. 1:24-28.

[4]. D. V. Rosatto, N. R. Schott, and M. G Rosato, Injection Molding Handbook. 3th Edition.Boston: Kluwer Academic Publisher; 2000.

[5]. Fimmtech Inc. Polymers and Plastics. http://www.fimmtech.com/index.php. diunduh pada 5 April 2016.

[6]. Research gate. Melt Filling Flow Behaviors in The Filling Stage. https://www.researchgate.net/figure/.diund uh pada 5 April 2016.

[7]. Georg Menges and Paul Mohren, How to Make Injection Molds. 2nd Edition, Hanser Publisher, New York; 1993.

[8]. Harper.Charles A. Harper, Handbook of Plastic Processes, John Wiley and Son, Inc., Publication, 2006.

[9]. Sinotech, Inc. 2014. Injection Molding. http://www.sinotech.com/injection molded.html. diunduh pada 18 Maret 2016 